\title{
Reflections of Industrial Revolution on Work Life in England and Its Projections in Literature: An Analysis on Charles Dickens's Hard Times*
}

\author{
Hatice Ozutku ${ }^{\mathrm{a}}$, Yasemin Tekinkaya ${ }^{\mathrm{b}}$, Tuba Vural ${ }^{\mathrm{c}}$
}

\begin{abstract}
The Industrial Revolution, which began in England in the eighteenth century, is the result of a long period of social and economic evolution extending into the late Middle Ages. Apart from its several favorable outcomes, Industrial Revolution caused some undesirable outcomes for working life. The aim of this study is to inspect Dickens's Hard Times which can be counted as one of the preliminary works that reflected on effects of Industrial Revolution on working life with a critical perspective within the scope of administrative mentality of that time. Within this context, scientific works which focused on the intellectual foundations of the industrial era and Dicken's Hard Times are taken into consideration for the conceptional framework of the study. Qualitative research approach has been adopted to the study and through the inspection of the novel, the main perspectives which make up the foundations of management mentality have been evaluated. As a result of this study, it is seen that positivitism, economy science and utilitarianism have been influential in the management concept and practices of the Industrial Revolution era. In Hard Times, Dickens propounds the negative effects of these perspectives which can be useful for the humankind when used for good causes.
\end{abstract}

\author{
Keywords: Industrial \\ Revolution in England, \\ History of Management, \\ Charles Dickens, Hard Times, \\ Positivism, Work Life
}

JEL: BOO, MOO, LOO

$\begin{array}{ll}\text { Received } & : \text { 04 June } 2018 \\ \text { Revised } & : 24 \text { July } 2018 \\ \text { Accepted } & : \text { 13 August } 2018 \\ \text { Type } & : \text { Review }\end{array}$

\section{Introduction}

Before the Industrial Revolution, production was made through simple tools and with the contribution of family members at homes or workshops nearly in every part of the world. After the Industrial Revolution, production was moved to machines and factories. Sophisticated machines were manufactured in the 18th century. In parallel with the invention and development of steam engines, these machines were used with steam power. Great industrial cities were founded with the Industrial Revolution. An important proportion of the population started to work in industry at the end of the $18^{\text {th }}$ century and beginning of the $19^{\text {th }}$ century (Günay, 2002). This era has been an important term for humankind because an age of technological innovations and industrial development started with the main discoveries and inventions of Industrial Revoluation such as steam engine, cotton yarn spinning machines, coke and steel production.

a Prof., PhD., Afyon Kocatepe University, Faculty of Economics and Administrative Sciences, Afyonkarahisar, Turkiye, hozutku@aku.edu.tr (ORCID ID: 0000-0003-0425-4967)

b PhD. Candidate, Afyon Kocatepe University, Institute of Social Sciences, Afyonkarahisar, Turkiye, yasemintekinkaya@gmail.com (ORCID ID: 0000-0002-4506-293X)

Lecturer, PhD. Candidate, Afyon Kocatepe University, Institute of Social Sciences, Afyonkarahisar, Turkiye, tubavural@aku.edu.tr (ORCID ID: 0000-0003-1737-4343)

* Bu çalışmanın bir kısmı 26. Yönetim ve Organizasyon Kongresinde bildiri olarak sunulmuştur. 
Industrial Revolution spreaded from England to Europe, to North America and the rest of the world (Allen, 2012). But the factory system posed new problems for owners, managers, and society at large. To be precise for the working class, these problems included the negative influence of hard working conditions on the increasing number of child and female labour, poverty, and long working hours (Wren \& Bedeian, 2009: 59-61).

Both the writers, poets (Carlyle, 1843; Disraeli, 1845; Dickens, 1848, 1854, 1861, 1983; Fitzgerald, 1925; Butler, 1926) and scientists (Engels, 1845; Mills, 1861; Comte, 1964, 1908; Marx, 1849, 1850, 1898; Durkheim, 1893) who analyzed and criticized that era are stressed similar topics. As one of the pioneering figures of industrial novel, Charles Dickens challenged economists through his fiction and his journalism (Henderson, 2000: 141).

Dickens reflected the working and living conditions of the working class in his novel Hard Times which included tiring and deadly working environment, unionization struggles, employers' attempts to push down these attempts, work accidents and Poor Laws, and he portayed the life in industrial cities in the era after the Industrial Revolution (Makal, 2008; Çiçekler, 2010). Three separate stories which are connected to each other are told in the novel. The first one is the story of a little girl named Sissy who is left to Coketown and needs to work in a circus in order to go to school. The second story is the story of Gradgrind's children, Louisa and Tom. The third story is the story of a worker, Stephen Blackpool and his girlfriend Rachel. In these stories Dickens aimed to criticize the failing education system and portray the living conditions of working class in Coketown (Urgan, 2003).

The novel has been scrutinized by several scholars from various perspectives. For example, Üskent (2006) examined the mathematical figures in Hard Times which can be accepted as one of the reflections of Industrial Revolution. Johnson (1989) used factory metaphor for the analysis of Hard Times and compared the monotony in every field of life during the industrial revolution to the operation of a factory. Balkaya (2014) focused on Dickens's Hard Times (1854), Charlotte Bronte's Shirley (1849) and Elizabeth Gaskell's North and South (1854-5) which are considered as industry age novels and inspected the social, political and economical problems, education, poverty, working conditions in factories, status of the women in the society and child abuse in the age of industrialization. Menteşe (2015) analyzed the same novels in the light of New Historical Criticism and scrutinized how these novels reflected the norms brought by industrialization, their interaction with the problems of the Victorian Age and the writers' attempts to change these problems. Stoler (1985) made a metaphorical analysis of novel characters and their names. Apart from these studies, there are several studies which focused on Hard Times (Fielding 1953; Bratlinger, 1971; Butwin, 1977; Bernard, 1987; Chapman, 1993; Pittock, 1998; Silva, Zimbrao, Lennard, 2000) but it is observed that Hard Times has not been examined in terms of the impacts of Industrial Revolution on management science. As for that, it is thought that this study will contribute to literature.

From novel to story and from poetry to essay, nearly every kind of literature is the kind of of texts which reflect the social life at most. Literary texts are important works of art which reflect formations of social life that do not find a place in scientific studies very much and sometimes impossible to present in such studies and add them a value. Literary texts can examine a social milieu, personal relationships, experiences and feelings which is generally impossible to portray in academic studies (Makal, 2008). For this reason, it is useful to look into the novels of the Victorian age which were also important for the reading society of the age (Urgan, 2003: 951). Within this pespective, Dickens's Hard Times brings a lively atmosphere to the present time which is impossible to portray through objective analysis. Furthermore, Stoler (1985:153) said " $[\mathrm{h}]$ is describing of scene, drawing of character, and rendering of dialogue are almost unrivalled in English fiction". Moreover, the Manchester Guardian (1849) identified Hard Times as a form of current history or journalism masquerading as a novel:

"There are popular works published in the form of novels that depict either important historical events of bygone years, or the passing realities of the present, in such an intense manner that the impression conveyed is stamped more vividly and indelibly on the mind . . than from the study of history properly so called" (Butwin, 1977: 168). 
Today, multidisciplinary studies have gained acceleration in social sciences as in other fields of science. In this study, Charles Dickens's Hard Times which stands as a document of business history and reflects the impacts of Industrial Revolution on work life in England has been evaluated from the perspective of management science. Within this context, scientific works which focused on the intellectual foundations of the industrial era and Dickens's Hard Times constitute the conceptional framework of the study. By basing the study on qualitative research approach, perspectives which make up the foundations of management mentality born from the factory system of the industrial revolution has been scrutinized through descriptions in Hard Times. While criticizing positivism which dominated the working life of the age, economy science and pragmatism, Dickens aimed to portray not the negative effects of these perspectives which emerge when they are used inapropriately rather than their benefits when they are used on their own (Üskent, 2006: 18). The target of Hard Times is not pragmatism or political economy at large but some aspects of pragmatism and some results of political economy. As Bernard notices, the novel, in fact, targets all the tendencies of the age which attempts to suppress the creative imagination of the people, to kill their individuality and to make them a cog in the whells of a machine or a student number in a class or a pair of "hands" without bodies and brains (1987: 44).

\section{Industrial Revolution in England, Victorian Age and Charles Dickens}

Textile was the main industry of Great Britain in Victorian Age. Cotton, wool and other fibers which came from the colonies were turned into cloth or other fabrics through cleaning, combing, spinning etc. Mechanical improvements in textile industry preceded the Industrial Revolution. Adam Smith and James Watt were the main responsible scientists for destroying the old Britain, and building a new one, and directing the world toward industrialization. While Smith formed the revolution in economic thought and Watt engineered the steam engine. Thus, steam power lowered the production costs and prices, and expanded the markets. A spirit of innovation led to inventions, inventions led to factories, and factories led to a need for direction and organization. The expanded market called for more workers, more machines and a larger production scale on a regular basis. Capital was needed to finance these larger undertakings, and the individuals who could command the capital began to bring workers and machines together under one common authority (Wren \& Bedeian, 2009: 40-42).

Industrial Revolution started with the reign of Queen Victoria in 1837. This era covers a long period more than half of the nineteenth century. In the early periods of Queen Victoria's reign, there were various problems in the country because of the fast and irregular development of industry (Abrams, 1993: 891). While the middle class was prospering, the working class which made up the majority of the population was heading towards poverty and there was a migration towards cities which resulted in an increase of population in suburbs. Furthermore, developments in science shaked the faith in belief and there was a moral corruption (Carter McRae qtd. in Saltan, 2009:30; Urgan, 2003). Apart from social transformation, the emerging factory system posed several management problems different from those ever encountered before. The church could organize and manage its properties because of dogma and the devotion of the faithful people; the military could control large numbers of personnel through a rigid hierarchy of discipline and authority; and governmental bureaucracies could operate without having to meet a competition or show a profit. The managers in the new factory system could not resort any of these devices to ensure the proper utilization of resources (Wren \& Bedeian, 2009: 43).

Industrialisation created a lucky upper class without offering any benefits to other classes. This strange contradiction coming with the Industrial Revolution was a usual conflict of the Victorian era. Apart from Dickens, many writers of the age wrote on this topic and the ones who criticized the social structure of thought were named as reformers and their novels were classified as novel of social reform rather than a social novel (Butwin, 1977).

Wren and Bedeian (2009: 46-47) argue that the contradiction lived in factories was because of the lack of discipline. Because in opposition to the traditional aspect, new factory system demanded regularity rather than spurts of work, and accuracy and standardization rather than individuality in design and methods. Workers who were accustomed to the independent traditions of craft and the agrarian mores of self- 
sufficiency, had to develop habits of industry, such as punctuality, regular attendance, the acceptance of a new regime of supervision, and the mechanical pacing of work effort. Dickens wrote on this contradiction in his weekly published magazine Household Words (HW):

"As one half of the world is said not to know how the other half lives, so it may be affirmed that the upper half of the world neither knows nor greatly cares how the lower half amuses itself" (HW 1, 13).

Again, in another article he mentions that the working class who is considered on the same level with the machines has a right of amusement. Throughout novel he reminds his audience that, if you are reading this article you are not a part of the other half (Butwin, 1977: 171). Orwell (1940) notes that Dickens's nearly all novels deal with this contradiction:

"In Oliver Twist, Hard Times, Bleak House, Little Dorrit, Dickens attacked English institutions with a ferocity that has never since been approached. Yet he managed to do it without making himself hated, and more than this, the very people he attacked have swallowed him so completely that he has become a national institution himself".

Dickens's Hard Times is based on his observations in industrial cities where he visited a woollen factory, a carpet factory and a cotton factory (Bratlinger, 1971: 276). Furthermore, Dickens visited the poorest streets of the cities he visited and made observations in order to reflect the effects of Industrial Revolution on social life (Urgan, 2003: 989). His first impressions of the factories when he visited them for the first time in 1838 were very hostile. It is possible to observe Dickens's hostile attitude to factory conditions and his siding with the working class in his letters to Mrs. Dickens, to Staples (Henderson, 2000: 142) and in his articles in HW. Eventually, Dickens planned to attack the factory system in one of his novels on the basis of his trips and his readings of Parliamentary reports. He was aware of the need for the laws to protect factory workers from dangerous working conditions, and he came to advocate a national insurance program for the lower classes (Bratlinger, 1971: 278). In one of his letters, he wrote to E. M. Fitzgerald (Bratlinger, 1971: 270-276):

"I have seen enough for my purpose, and what I have seen has disgusted and astonished me beyond all measure. I mean to strike the heaviest blow in my power for these unfortunate creatures..."

Thus, Dickens stroke the heaviest blow in his power in Hard Times. The novel seems obviously different from most of the other novels, because it shows a comprehensive vision of contemporary society rather than the usual series of scenes, each of which is too heavily stressed to have any significant relation to one another or to the work as a whole. Hard Times reveals Dickens's ambivalent feelings towards industrialism as clearly as any of his other novels (Fielding, 1953: 270). As Johnson notices it "does recreate the dynamics of capitalist production" (1989: 135). When looking at the early management history literature, critics (Wren \& Bedeian, 2009: 55) have charged that capitalism, together with its offspring -the market and factory system- robbed people of a golden age of equality and freedom. More specifically, the criticism argued that the people were enslaved to the owners of capital and they became a commodity in the market place of life, capitalists exploited child and female labor and industrialization created poverty, urbanization, pollution and a host of other societal ills.

There can be no doubt that Dickens was concerned about the factory problem throughout his career. Dickens was a disbeliever in the past and a supporter of the new industrialism (Johnson, 1989: 129). Throughout Hard Times, he does not suggest the destruction of the factories, or the establishment of any other new economic system, or even the passage of more factory laws. He only suggests that the factory owners should scrap their plea of laissez-faire and abide by the existing laws which prescribe the education of factory children, the appointment of inspectors to look into their works, the fencing of dangerous machinery to avoid chopping people up, and smoke abatement (Bratlinger, 1971: 280-284). In spite of these issues, one might ask how the condition of England is to be improved by telling tales. Through the agency of fancy and imagination which could be inferred from the novel, a whole class may be able to adopt the experience of another class (Butwin, 1977: 170). 


\section{Depiction of the Industrial City, Working Conditions, Factory Owners and Workers in Hard Times}

Dickens travelled to Preston in 1854. He viewed the bitter strike and lock-out in Preston as a deplorable calamity. His article about the strike in Preston was published in Household Words and about three weeks later Dickens began writing Hard Times (Spector, 1984: 369; Henderson, 2000: 148). Hard Times is a representation of industrialism. The imaginative constraint of Hard Times is the symbolic expression of Dickens's critique of the interlocking structures, economic, social, and political reflections of industrial capitalism. As a realistic description of the industrial city and the industrial worker, it has been compared to blue book reports, to the work of Friedrich Engels and other commentators on the emerging industrial society, and to Dickens's own journalistic description of the Preston strike (Johnson, 1989: 128). Dickens reflects his observations of industrialism after his visits to newly developing industrial cities and Preston in Hard Times as:

"It was a town of machinery and tall chimneys, out of which interminable serpents of smoke trailed themselves for ever and ever, and never got uncoiled. It had a black canal in it, and a river that ran purple with ill-smelling dye, and vast piles of building full of windows where there was a rattling and a trembling all day long, and where the piston of the steam-engine worked monotonously up and down, like the head of an elephant in a state of melancholy madness" (Hard Times, 34).

In Hard Times, Dickens reflects sultry atmosphere of industrial cities through his observations. Inhabitants of industrial cities were badly affected by polluted air. For instance, the "Great Smog" was an extremely dense and polluted fog affecting the whole of the London area. It caused deaths of a vast number of people. There are several studies investigating the hospital records about this topic (Bell \& Davis, 2001; Davis, Bell \& Fletcher, 2002; Black, 2003; Bharadwaj, Zivin, Mullins, Neidell, 2016). Although this air pollution which was known as the Great Smog affected life in London in 1952, the conditions of the other industrial cities were not different.

While describing the air pollution in Coketown in Hard Times, Dickens likens the industry city to a factory with its standardized lives of workers who had similar daily lives. Furthermore, the city has a factory like shape with its working class slums which provides the fuel for the system. Dickens uses the metaphor of the society as a family to organize the novel. Hard Times uses the physical structure of the factory itself as both the metaphor for the destructive forces at work on its characters' lives and as the metaphor for its own aesthetic unity as a novel. As Johnson (1989: 129-132) notices the slums are the habitats of the factory hands and "when they die, black ladders are raised to the windows to dispose of the dead, the sliding away of all that was most precious in this world to a striving wife and a brood of hungry babies, like coal down a chute". Monotony in Coketown is described as:

"It contained several large streets all very like one another, and many small streets still more like one another, inhabited by people equally like one another, who all went in and out at the same hours, with the same sound upon the same pavements, to do the same work, and to whom every day was the same as yesterday and tomorrow whom every day was the same as yesterday and tomorrow, and every year the counterpart of the last and the next" (Hard Times, 34).

The machines of Coketown represent a monstrous life with their continuous clangs which sound like "melancholy mad elephants". The city provides a dreary death scene and the factory scenes are much more psychological with its cure lying on providing a natural harmony between workers and factory owners (Bratlinger, 1971: 281). According to Spectator (1981: 377) Dicken's assertion that Dickens's generalized portrayal of the people of Coketown embedded in the metonymy of the city and its inhabitants is in fact his association of machine and labor which reinforces the workers' character. Within this framework, Dickens's characterization of the labor and description of the city is unique. In Dickens's criticism of the ugliness and monotony of the city, there is no hope of returning back to the preindustrial conditions or a utopia of a brighter future (Bratlinger, 1971: 283).

Dickens portrays the present conditions as far as possible in order to show the necessary amendments that should be made. In spite of his dark criticism of the industrial city, Dickens is not against 
industrial revolution. He only stresses the need for a betterment of the present order. In the novel, the character Bounderby hardly suits to the bloody tyrant character of the factory owner. Although he can be seen as a deplorable character, as a factory owner he aims to keep his factory working whatsoever happens to his workers without having any sympathy for them. He does not care about the wages or conditions of his workers in his factory. As Fielding (1953: 272) notes, the factory owners are mean and selfish people since they have too little trust and good will between them. While they are ready to pay high prices for machines, they do not show the same willingness for workers and try to keep their expenses as low as possible. For this situation, Urgan (2003) notes that while the British workers had the pride to be the richest country in the world, they were forced to live with their wives and children in mines or factories under terrible conditions which were worse than slaves. The conditions of the workers of Coketown were the same. They were working for very small amounts under terrible conditions and they were very unhappy. However, according to the mentality in Coketown the poverty and unhappiness was their mistake:

"Any capitalist there, who made sixty thousand pounds out of sixpence, always professed to wonder why the sixty thousands nearest hands didn't each make sixty thousands pounds out of sixpence and more or less reproached them every one for not accomplishing the little feat. What I did you can do, why don't you go and do it?" (Hard Times, 121).

The workers are mentioned as "hands" in the novel and among the society of the age since they were not counted as real personalities who had hearts and souls. It was a difficult job to discipline these "hands" who did not attend to church and were always ready to show ingratitude to their bosses (Urgan, 2003: 1026). Coketown as a milltown showed the polarization between the industrialists and the working class people (Johnson, 1989: 129).

"So many hundred Hands in this Mill; so many hundred horse Steam Power. It is known, to the force of a single pound weight, what the engine will do; but, not all the calculators of the National Debt can tell me the capacity for good or evil, for love or hatred, for patriotism or discontent, for the decomposition of virtue into vice, or the reverse, at any single moment in the soul of one of these its quiet servants, with the composed faces and the regulated actions" (Hard Times, 68)

It is possible to observe the status gap between the factory owners symbolized by Bounderby and the workers in the novel:

"...Her own private sitting-room was a storey higher, at the window of which post of observation she was ready, every morning, to greet Mr. Bounderby as he came across the road, with the sympathising recognition appropriate to a victim." (Hard Times, 116).

Throughout the novel, the unfortunate relationships between the workers and factory owners have been portrayed frequently. For example, Stephen's case when he falls down Old Hell Shaft can be given as an example of unfortunate relationship because the mine owners neglect to close up abandoned pits. Dickens writes about the employer-employee relationship which is frequently stressed in the novel in an article he penned for Household Words:

"I believe... that into the relations between employers and employed, as into all the relations of this life, there must enter something of feeling and sentiment; something of mutual explanation, forbearance, and consideration and is not exactly stateable in figures; otherwise those relations are wrong and rotten at the core and will never bear sound fruit. (Henderson, 2000: 149).

Furthermore, in Hard Times the trade union does not satisfy the demands of working class people for better wages, shorter working hours and more benefits. Dickens does not deal with a strike or the working conditions in the factories. He does not even go into the details of the misery of working class people. Bounderby's narrowminded selfishness shows itself as a sign of natural response to his workers by bullying of them (Bratlinger, 1971: 280-284). In addition to this, Mr. Gradgrind's utilitarianism and the circus's traditional humanism compete with each other (Johnson, 1989: 129). The steam engines which are the symbol of industrialism are very important for Dickens that he keeps the steam whistle party continue. Dickens even wrote in one of his articles: "there is a range of imagination in most of us which no amount of 
steam-engines will satisfy". As Bratlinger (1971: 280-284) notices, Dickens hopes in the novel that the workers will get higher wages and better conditions, but they need fun more.

\section{Reflections of the Dominant Paradigm in Hard Times during the Industrial Revolution Era}

From a philosophical perspective, the theoretical premises of Industrial Revolution are paved mainly by positivism, economics and utilitarianism. Positivism has been theoretized by the French social scientist August Comte. According to Comte, positivist philosophy adjusted the chaos which came out after Enlightenment. Positivist thought stood against idealogies, teologic and metaphysical thought in the first place. Comte stresses the importance of positive/scientific knowledge. Accordingly, non-scientific ideas are evaluated as nonsense. For information to gather a scientific nature, it must be based on observation and tangible data (Atila Demir, 2009; Sönmez, 2010). Comte's thoughts were systematized through John Stuart Mill (1806-1873) and Emile Durkheim's (1858-1917) studies and the foundations of positivist thought have been laid (Sönmez, 2010; Gürbüz \& Şahin: 2014: 31; Neuman, 2017, translated by S. Özge).

Positivism is a period in the middle of the $19^{\text {th }}$ century when the positive thought emerged in France, England and Germany. The age of science started in this period. Because the society was living in the ScienceIndustry age which was led by Enlightenment, French Revolution and Industrial Revolution (Ballıkaya, 2015). The new way of life which was based on science and mechanics together with the thought of Enlightenment had features which prioritized consumption of specialized machine produced goods rather than thriftiness of agricultural production based on muscle power. It was necessary to direct these changes in the society which was freed from the structure of the middle ages and saw fundamental changes in every field according to positivist principles. At this point, positivism had an important role (Ballıkaya, 2015). The individual who produces knowledge should be impartial and should not blend his or her own thoughts. An impartial scientist and objective data are the main acceptances of Enlightenment (Aslan Yaşar, 2011: 18). General thought of Positivism, as in physics, is that it can reach definite results about realities (Ballıkaya, 2015).

Political Economy Science or Economy Science with its contemporary name is one of the most important foundational premises of Industrial Revolution which was first defined by the Scottish economist, Adam Smith (Smith, 1948). In his work The Wealth of Nations which was published in 1776, Smith evaluates the factory system and man power as the source economic wealth rather than agricultural production. He asserted that the sources can be used efficiently with the human labour and division of labour designed as an assembly line, and the national income rises with the production (Smith, 1948). Adam Smith argued that the mechanism of the market will regulate the structure of the society as an "invisible hand", and as long as the individuals acted according to their needs, national wealth will increase constantly while any kind of intervals with the market will affect the natural flow of the economy and hinder the maximization of social benefits (Günay, 2002).

The first traces of utilitarianism in economics can be seen in Adam Smith's Wealth of Nations which affected the structure of the industrial thought as one of its baselines. Smith's inferences about the individual type who thinks about his/her benefits provided an alternative for the ethics which relied on the natural legal philosophy of the age (Ackermann quoted in Seker \& Çetin, 2012). Smith's thoughts were evaluated by Jeremy Bentham, one of his contemporary British reformists. They were reinterpreted as the greatest happiness of the greatest number principle and commented on a work titled The Principle of Utility which led to the rise of Utilitarianism (Bentham quoted in Üskent; Möngü, 2015; Başok Diş, 2017). In fact, the leading figure of utilitarianism which has an important place in the scientific thought of Enlightenment is Francis Bacon (Şaylan, 2002:165). According to Bacon, the individual has to be the master of the world and know nature which is a great force in order to control the objects and transform them for his or her benefits. The main purpose of science is to decrease the despair of the human kind and to glorify it. Through science and knowledge, human beings can dominate the nature and use it for their benefits and happiness (Aslan Yaşar, 2011: 18). In this respect, pragmatism or utilitarianism has been influential in the thought of industrial era by arguing that the "good" is equal to happiness or pleasure as a general economics teaching and as political and social theory (Cevizci, 2000: 1005; Başok Diş, 2017). According to the utilitarian understanding accepted by economy science, the aim of all economic activities such as production, consumption and sharing is to 
maximize the benefits gained from goods and services. In this respect, rational individual is the person who maximizes his or her benefits and as a result his or her happiness through limited resources (Seker \& Çetin, 2012).

It can be deduced that the movement of utilitarianism provided a basis for a concept which can be named as "Homo Economicus". This concept stands for a person who maximizes his or her wealth. In its foundations, it has Bentham's psychological axiom of "individual is a pleasure seeking and pain avoiding entity". Homo Economicus can be defined as the rational person who runs after benefit maximization as a consumer and profit maximization as a producer (Akyıldız, 2008: 29). As Da Silva and Lenard notes, Homo Economicus is motivated by the rational dynamics seeking profit based on free enterprise (2000: 43). Positivism, which provided the dynamics of the industrial revolution, economy science and utilitarianism have been the target point of Dickens's works. It is possible to observe the reflections of positivism on the characters and their names even before the plot of the novel is settled in Hard Times (Bounderby, Mr Harthouse, Gradgrind and Choakumchid, Bitzer and Sissy Jupe, Blackpool and Louisa). According to Stoler (1985) "It is this kind of name one with its roots in literal referents outside the character and therefore able to assume a metaphoric function - that Dickens uses most frequently in Hard Times... he relies heavily on symbol and metaphor to condense and advance meaning".

Bounderby: Dickens pictures the cruel and crooked capitalist order through tradesman and factory owner Bounderby (Urgan, 2003: 1031). Bounder means a vulgar worthless person who has no traits of gentleness. Bounder shows off his vulgarity through his wealth and the false humility he attracts on himself. The bounder character through its namesake represents the vulgarity of a newly emerging class which does not have any eloquence and lack the education and refinement of a certain class. Although he was not educated according to utilitarian principles, Bounderby embraces the principles of the movement (Stoler, 1985: 156).

Mr. Harthouse: His name sounds like 'hothouse'. A hothouse is like a greenhouse where plants are raised artificially and for this reason his name refers to artificiality. His name also sounds like heart which symbolizes the stereotypical kind of lovers in romantic novels. Throughout the novel, the reader grasps that his love is insincere like his other actions. As Stoler notes that his insincerity is suggested through these quite different homonyms of 'heart' and 'hothouse' of his name (1985: 164). It can be deduced that his heart is kept in a hothouse where it is artificially developed. For Dickens, he stands for the aristocratic decadence. In the novel, he reveals the effects of Utilitarian education on Louisa.

Gradgrind and Choakumchid: Gradgrind and Choakumchid symbolize the effects of education system. Gradgrind provides an education which is based on grinding the students. Eventually nothing is left in their minds apart from facts. For this reason, Gradgrind stands as a man of realities. He is keen on facts and calculations. He always carries a ruler, a pair of scales and a multiplication table in his pocket in order to weigh and measure any kind of parcel and tell the contents of it. For him, it is a mere question of facts and figures, a case of simple arithmetic (Chapman, 1993: 2). Dickens also provides the ground for turning down the mentality of the industrial revolution through Gradgrind's own teachings (Çiçekler, 2010). It is also meaningful for Dickens to choose Choakumchild for a character who takes positivist paradigm as a principle with a name which sounds like 'choke' and 'child' (Urgan, 2003: 1028). He stands for the effects of Utilitarian education on children.

Bitzer and Sissy Jupe: While Bitzer symbolizes the positive outcomes of the utilitarian education system, Sissy Jupe reveals the negative outcomes of this system. As his name reveals, Bitzer has the bits and pieces of inadequate education and has nothing to develop his imagination. He is consumed by facts. He is a product of Gradgrind's education system based on factual knowledge. Sissy Jupe does not stand as an example of such education. Because her spirit and emotions could not be extinguished by her teachers. For this reason, her name is unified with sun and light and it sounds like 'sister' since she relies too much on her emotions (Stoler, 1985: 160).

Blackpool and Louisa: As an honest worker, Blackpool is the spokesperson of the working class and mouthpiece of Dickens. Louisa Gradgrind is the daughter of the Mr. Gradgrind who symbolized the Utilitarian 
thought. The novel presents the women as the fuel of the system. Blackpool has a life which symbolizes the process of the factory. He acts as the furnace or the heart of the system. While Blackpool is in the center of production, Louisa stands in the center of marriage and reproduction. Dickens implicitly draws a paralled between the factory system and patriarchal family system (Johnson, 1989: 133-134). Besides Louisa's inability to distinguish between real lover and artificial exploiter, Harthouse represents Dickens's negative views about Utilitarianism (Stoler, 1985: 160). The life of these two characters, which stand in the central section of the novel stand as the fuel and the waste of the factory system. The plot of the novel starts with a stress to realities. With a positivist perspective, the novel stresses the realities achieved through scientific knowledge:

"Now, what I want is, Facts. Teach these boys and girls nothing but Facts. Facts alone are wanted in life. Plant nothing else, and root out everything else. You can only form the minds of reasoning animals upon Facts: nothing else will ever be of any service to them. This is the principle on which I bring up my own children, and this is the principle on which I bring up these children. Stick to Facts, sir!... In this life, we want nothing but Facts, sir-nothing but Facts! (Hard Times, 15).

Positivism argues that the only type knowledge which should be meditated is scientific knowledge. As in science, positivism argues that people can achieve definite results in terms of realities. Gradgrind and his school are frequently stressed in the novel as a means of positivist education system. Louisa, Tom, Bitzer and Sissy are all products of this education system, either positive or negative. Gradgrind's remarks towards Louisa show the dimensions of the positivist education system:

"You have been so well trained, and you do, I am happy to say, so much justice to the education you have received, that I have perfect confidence in your good sense. You are not impulsive, you are not romantic, you are accustomed to view everything from the strong dispassionate ground of reason and calculation. From that ground alone, I know you will view and consider what I am going to communicate." (Hard Times, 101).

For example, Gradgrind asks Bitzer as a representative of positivist perspective to define a horse. With and observable and countable tangible information, Bitzer defines it as:

"Quadruped. Graminivorous. Forty teeth, namely twenty-four grinders, four eye-teeth, and twelve incisive. Sheds coat in the spring; in marshy countries, sheds hoofs too. Hoofs hard, but requiring to be shod with iron. Age known by marks in mouth." (Hard Times: 18).

Dickens stresses frequently on measurement which is a keystone of positivist philosophy. Gradgrind whose voice is like a squeaks of a senseless machine, only gives importance to calculations. He takes facts into account. This situation can be clearly seen in the following statements:

"Thomas Gradgrind, sir. A man of realities. A man of facts and calculations. A man who proceeds upon the principle that two and two are four, and nothing over, and who is not to be talked into allowing for anything over... With a rule and a pair of scales, and the multiplication table always in his pocket, sir, ready to weigh and measure any parcel of human nature, and tell you exactly what it comes to. It is a mere question of figures, a case of simple arithmetic.... In such terms Mr. Gradgrind always mentally introduced himself. (Hard Times, 16).

The effects of positivist thinking and utilitarianism did not only stay within the borders of factories and Gradgrind, they also effected education system deeply. It is possible to see to what extend has positivist thinking influenced daily life from a speech of Gradgrind with his students:

"You are to be in all things regulated and governed by facts" said the gentleman. We hope to have, before long, a board of fact, composed of commissioners of fact, who will force the people to be a people of fact, and of nothing but fact. You must discard the word Fancy altogether. You have nothing to do with it. You are not to have, in any object of use or ornament, what would be a contradiction in fact. You don't walk upon flowers in fact; you cannot be allowed to walk upon flowers in carpets. You don't find that foreign birds and butterflies come and perch upon your crockery; you cannot be permitted to paint foreign birds and butterflies upon your crockery. You never meet with quadrupeds going up and down walls; you must not have 
quadrupeds represented upon walls. You must use," said the gentleman, "for all these purposes, combinations and modifications (in primary colours) of mathematical figures which are susceptible of proof and demonstration. This is the new discovery. This is fact. This is taste." (Hard Times, 20).

In the novel, it is stressed that the children should evaluate everything through addition, subtraction, multiplication and division and act according to principles of rational thought. Positivist thinking has adopted a mechanical approach. Individuals have limited freedom for realizing their wishes. Because they choose rational behavior by thinking the outcomes of their actions. According to this, organizations teach their workers to act in a standardized and consistent way and see them as replacable elements, they can achieve high productivity and efficiency (Starbucks quoted in Keskin et.al, 2016: 156). In Hard Times, the system defended by Gradgrind summarizes pure positivism. Children are evaluated as simple machines which will be useful in the future rather than being individuals. According to Gradgrind, the minds of the children have the same size of cups which came out of the same machine (Urgan, 2003: 1028). The statements of Mr. Choakumchild given below summarize the reflections of this perspective in education system:

"Now, besides very many babies just able to walk, there happened to be in Coketown a considerable population of babies who had been walking against time towards the infinite world, twenty, thirty, forty, fifty years and more... Still, although they differed in every other particular, conceivable and inconceivable (especially inconceivable), they were pretty well united on the point that these unlucky infants were never to wonder. Body number one said they must take everything on trust. Body number two said they must take everything on political economy. Body number three wrote leaden little books for them, showing how the good grown-up baby invariably got to the savings-bank, and the bad grown-up baby invariably got transported. Body number four, under dreary pretences of being droll (when it was very melancholy indeed), made the shallowest pretences of concealing pitfalls of knowledge, into which it was the duty of these babies to be smuggled and inveigled. But all the bodies agreed that they were never to wonder" (Hard Times, 5960).

Dickens's statements about grown-ups as babies show that the factory system hinders workers or individuals to mature and turn them into passive and addicted workers who obey without thinking and questioning. A good baby is a person who obeys, acts according to the rules of the rational system and chases after his or her own benefits. A bad baby stands for the individuals who question the factory system and cannot earn anything as a result.

While homo economicus stands for a hedonist person who pursue benefits in ethics, in economic life it stands for a person who acts rationally (Akyıldız, 2008: 39). In the novel, Bounderby stands as an example of homo economicus. Besides, as an individualist, he believes that he owes his success only to himself alone. In a capitalist economy, the individual is responsible for determining his or her place in the society. As Da Silva and Lenard notes, Bounderby who stands as an example of homo economicus becomes rich through individual effort and work to the point of exaggeration (2000: 49). Besides, Bitzer is another species of homo economicus who evaluates everything in terms of money and individual profits. According to him, the only of a human being in the world is to buy a thing with the least money and to sell it as expensive as possible. Human beings have no other function, and it is not right to have any other function. In the novel, it is a good example of rational behavior in economic life when Bitzer gives away Tom in order to take his place.

Robert Owen (1771-1858), Charles Babbage (1792-1871), Andrew Ure (1778-1857) and Charles Dupin (1784-1873) are pioneers of management who lived in the same century with Charles Dickens (18121870. They formulated the seeds of the management discipline. Beside these names, many pioneers have provided the necessary substructure before the scientific management era. For example, Babbage asserted that machinization increases the wealth level of a country and economic principles have a contribution in this as well as mechanical principles. Furthermore, Babbage is in the same opinion with Adam Smith in terms of accepting work division as the foundation of factory order. Like Dickens, Owen saw the dangers of the industrialism and found it necessary for a new moral order based on a social reorganization He also attempted to improve the living and working conditions of child workers. Ure designed manager types for new factories and Dupin started management classes. All these names attempted to catch the attention of 
factory owners who focused on improving machines, specializing labor and cutting costs rather than investing in human resource. However, they could not succeed in persuading the other scientists that the reform was realistic rather than Utopian at the time (Wren \& Bedeian, 2003).

\section{A Critical Overview of Positivist and Utilitarian Approaches in Hard Times}

It is understood that in Hard Times Dickens criticizes the positivist approach and utilitarian thought which were dominant in Europe during the Industrial Revolution and their malpractices rather than the negative effects of revolution on workers and society. Dicken's approach to positivist paradigm can be evaluated in the light of "critical theory" which objects to the attempts of positivitism to reach a universal rationality. Critical theory is the first approach which stresses that science should be a liberating power for knowledge from every kind of domination (Keskin et. al, 2016: 419). The views of Karl Marx (1818-1883) who lived in the same era with Dickens have been very influential in the rise of critical theory. While inspecting the development of the modern society, Marx criticized the increasing division between the owners of factories and industy who hold the power of production in their hands and people in the working lines (Keskin et. al, 2016: 429). It is possible to see these criticisms in the following lines in Hard Times:

"A town so sacred to fact, and so triumphant in its assertion, of course got on well?

\section{Why no, not quite well. No? Dear me!}

No. Coketown did not come out of its own furnaces, in all respects like gold that had stood the fire. First, the perplexing mystery of the place was. Who belonged to the eighteen denominations? Because, whoever did, the labouring people did not. It was very strange to walk through the streets on a Sunday morning, and note how few of them the barbarous jangling of bells that was driving the sick and nervous mad, called away from their own quarter, from their own close rooms, from the corners of their own streets, where they lounged listlessly, gazing at all the church and chapel going, as at a thing with which they had no manner of concern. Nor was it merely the stranger who noticed this, because there was a native organisation in Coketown itself, whose members were to be heard of in the House of Commons every session, indignantly petitioning for acts of parliament that should make these people religious by main force." (Hard Times, 35).

By showing that the working class has no relation to religion and has undesirable habits, Dickens addresses that there is a division between the workers and the people who control the working power. The novel presents the mistakes of the society starting from its roots. By looking at these roots it is possible to understand Dickens's position. His criticism of the society is based on moral foundations which are the law, state, educational system and so forth, but he does not offer a clear option instead of these things (Orwell, 1940).

The contribution of Habermas to the positivist criticism of critical theory is very important. He stands against the application of general laws in natural sciences to social sciences as the only defining factor. Habermas, who opposes the independence of positivism free from values principle, argues that human beings have relationships with their surrounding bordered with social norms, and the value which stresses this dialectic relationship is ignored by positivitism but the relationship between the value and concept is inescapable (Habermas qtd. in İspir, 2015: 73). Positivist perspective could not see the necessity to keep its distance with the reality for the movement of the thought and from this perspective created its own virtual empirical reality and furthermore turned it into the source of absolute truth (Rutli, 2014: 146). Character of Bounderby in the novel can be given as an example for this perspective. He argues that the poor people stay poor because of their laziness, if they worked they could be as rich as himself. He creates his own reality by telling lies constantly and and puts them into the source of absolute truth. According to Positivist perspective, facts are the roots of science and the realitionships between facts make up scientific laws (Burrell and Morgan qtd. in Keskin et. al, 2016: 148). However, in the novel, Gradgrind's daughter Louisa who was brought up with positivist educational system criticizes this system: 
"I wish I could collect all the facts we hear so much about," said Tom, spitefully setting his teeth, "and all the figures, and all the people who found them out; and I wish I could put a thousand barrels of gunpowder under them, and blow them all up together!" (Hard Times, 62).

Weakest sides of positivism have been evaluated by theoretical critics as overhauling of natural sciences in terms of obtaining positivist knowledge, finding metaphysics empty and meaningless, reducing the social world to data and their attempts to measure everything, parting concepts from their values and separating information from human will, and its close relationships with bourgeous thought (Atila Demir, 2009; Neuman, 2017, translated by S. Özge). Utilitarianism, one of the most influential and popular ethic theories of today, takes pleasure as a measure. However, its questioning by philosophers overshadows utilitarianism's popularity (Başok Diş, 2017: 80). Charles Dickens criticizes the approach of utilitarianism which promotes the progressive, concrete, measurable and utilisable knowledge and behaviour of the 19th century industrial society. In Hard Times, he examines the upbringing of individuals whose dreams are bordered and feelings suppressed through utilitarian education system and who ignore moral values and humanistic feelings for their own interests. Dickens states that the curiosity and questioning faculties of children are hindered by the current education system whose only goal is to add children into the capitalist work force (Düzgün, 2018). Human being is not always a rational entity. Sometimes, the main factors which define behaviours are habits, imitation and social norms rather than reason. For example, a human being can behave towards cooperation rather than his or her interests. Thus, utilitarianism approach fails to satisfy the human behaviour. Because, human beings are psychological entities rather than economic beings. For this reason, it is not possible to formulate behaviour with a certain definition (Akyıldız, 2008: 39). The statements of the circus owner, Mr. Sleary, one of the characters of the novel shows the invalidity of utilitarianism and stand as an opposition to the model of Homo Economicus.

"People must be amuthed thquire, thomehow....they can't be alwayth a-working, nor yet they can't be alwayth a-learning. Make the betht of tuth; not the wurtht." (Hard Times, 52).

Dickens recognizes the need to amuse as a basic human need (Butwin, 1977: 173). The opposition between the people of Coketown and circus people is striking in this sense. The people of Coketown give importance to personal benefits and money with a rigid selfishness. On the other hand, circus people are warm and humane, love each other and try to help each other as far as possible (Urgan, 2003: 1029). The workers of the circus are portrayed as poor people who do not have good educational backgrounds and do not have enough nutrition. In fact, their living conditions are not better than the workers in the industry wheel. However, their reason to be happy is related to their powerful social and emotional relationships.

In a sense, Dickens was able to influence the public opinion on some small but important issues. Despite his attempts to change the mindset of the society, some fixed evils cannot be healed (Orwell, 1940). While Gradgrind recognizes that there are some other factors other than the facts which influence the bad things happening to his son and daughter, Bounderby cannot get out of the dominant paradigm of the society when his wife deserts home. He stands rigid and stone hearted. Bourderby matches Louisa who rebels to him to the workers who cannot endure their fates. He thinks that Louisa shows ingratitude like the workers who constantly complain and wish to travel around with horse carts (Urgan, 2003: 1030). In fact, Dickens criticizes the economic, cultural and the mentality of the age with Hard Times. He stands against the misusage of positivitism, pure rationalism and rationality. He portrays the structure of the current system through Gradgrind and Mr. Choacumchild, the deficiencies of the current system through Sissy and Sleary's circus, and the necessity for transformation through Tom and Louisa, but he shows that the society is not ready for a paradigm transformation through Bounderby.

\section{Conclusion}

Dickens's Hard Times is among the first works which reflect the impacts of Industrial Revolution on working life in England through a critical perspective. In this study, Hard Times has been evaluated though positivism and utilitarianism which were the dominant perspectives on social and economic structures of the time. From a philosophical perspective, it is understood that the theoretical premises of Industrial Revolution 
is paved mainly by positivism, economics and utilitarianism. These three factors which can be defined as motor forces of Industrial Revolution have been the target of Dickens's works.

Industrial Revolution which started with the inclusion of new inventions to production has led to the transformation of production and rise of factory system. The most important feature of big and complex factories which separates them from the previous production units was the use of machines instead of human power. Entrepreneurs started to become responsible for the running of the new order because they were both the proprietor and controller, manager of the factory. The new factory system brought about managerial problems which were not encountered before. Bourgeoisie of the past who acquired trade as a business turned into the manufacturers with the rise of industrialism and did not know which systematic organization structure to take as an example and how to manage. In the same way, the managers of the new factory system did not know how to utilize their workforce and resources. Although the conditions were worse before the industrial revolution, Charles Dickens and other prominent Victorian figures established the rationale for criticizing the rise of the factory system (Wren and Bedeian, 2009: 59). The new factory system demanded regularity, accuracy and standardization rather than the individual efforts for running the work. Workers who were used to work independently in agriculture had to get used to the new habits of industry, such as punctuality, regular attendance, cooperation with the coworkers and the management and the mechanical pacing of work effort.

With the current system, factory owners were willing to pay high prices for machines while trying to decrease the costs of workers to the minimum. With the change in production methods, work power went under the domination of machines. Machines, the most important actors of Industrial Revolution, have marked not only the factory systems but also the lifestyles and thinking of the age. In addition to factories, education system and all the fields of life were dominated a mechanical thinking void from senses, humanity and benevolence. Life itself was considered to be an operating factory and turned into a mechanical thing designed with rationality principles. In Hard Times Dickens stresses that these assumptions are against the nature of human being. He draws attention to the fact that workers are not just production input, they need a healthy and safe working environment, they have feelings and ignoring such emotions may cause undesirable results.

Dickens is not totally against the Industrial Revolution which enhances the welfare of his country. He complains only about the bad conditions which come together with the revolution. Thus, he criticizes this situation mercilessly. He thinks that the revolution and humanistic feelings should go hand in hand. As a result, his country may turn into a more viable environment. Although Hard Times is generally considered to be a criticism of the hard facts of the age, Dickens attempts to renew and reduce these conditions (Butwin, 1977: 175). It is not only enough to have reason, reality and facts to understand the life, feelings are also necessary to understand the events. It would be easy to make sense of life with this holistic perspective.

Critical theory can be useful for evaluating Dickens's views on positivism. Critical theory objects to the attempts of positivitism to reach a universal rationality. In Hard Times, Dickens stresses frequently on measurement which is a keystone of positivist philosophy and its foundation mathematics. It is possible to see the use of mathematical images at schools, workplaces and every field of life in the novel. Dickens always points to a change of spirit rather than a change of structure (Orwell, 1940). In Hard Times, it is stressed that the utilitarian thought and Homo Economicus model do not match to the realities of life. With the Industrial Revolution, the structure of the society, and organic and cooperative production model which was based on human relations changed. Although the methods of production changed and became mechanized with the Industrial Revolution, humankind remained the same because of its nature. Since the feelings and requirements have been ignored, human beings could not adapt and fit into the new production system.

In his novels, Dickens inspects the social problems through a pragmatic perspective and argues that the education system should be corrected, little children should go to schools rather than being exploited in mines, poor people should live in better condtions. None of Dickens's suggestions are utopic (Urgan, 2003:996). He looks for a reality which is beyond imagination. However, he does not offer an escape from the system. He recounts the cost of maintaining the system (Johnson, 1989: 136). Dickens intends to go 
further than a surfacial reading of workers' reality and reveal them (Spector, 1984: 375). In Hard Times, the inability of the characters to reach happiness shows that there is no artificial solution to the realities of life (Urgan, 2003: 1032). Dickens believes that the reader of his novel will act in a different way. As Butwin notices, Hard Times, as a novel of social reform, completes itself outside the novel through different kinds of action such as joining of societies (1977: 167). In fact, the readers of Hard Times are asked to turn their attention away from the novel. In the final pages of the novel, Dickens makes his intentions clear:

"Dear reader! It rests with you and me, whether, in our two fields of action, similar things shall be or not. Let them be!" (Hard Times, 286).

\section{References}

Abrams, M. H. (1993). The norton anthology of english literature (6. Ed.). Vol:2, NY.

Akyıldız H. (2002). Tartışılan Boyutlarıyla "homo economicus". Süleyman Demirel Üniversitesi Iktisadi ve Idari Bilimler Fakültesi Dergisi, 13(2), 29-40.

Allen, R. C. (2012). The British industrial revolution in global perspective. UK: Cambridge University Press.

Aslan Yaşar, G. (2011). Ortaçağdan günümüze "modernite": Doğuşu ve doğası. Adıyaman Üniversitesi Sosyal Bilimler Enstitüsü Dergisi, 4(7), 10-26.

Atila Demir, S. (2009). Sosyal bilimlere eleştirel bir bakiş: Frankfurt okulu ve pozitivizm eleştrisi. SAÜ Fen Edebiyat Dergisi, I, 59-73.

Balkaya, M. A. (2014). Elizabeth Gaskell's North and South / Sanayi devriminin Charlotte Brontë'nin Shirley, Charles Dickens'ın Hard Times ve Elizabeth Gaskell'ın North and South romanlarına yansıyan etkileri. Atıım Üniversitesi Sosyal Bilimler Enstitüsü, Yüksek Lisans Tezi, Ankara.

Ballıkaya, C. (2015). Pozitivizm tarihsel süreç içerisindeki gelişimi ve sosyolojik düşünceye etkileri. Selçuk Üniversitesi Edebiyat Fakültesi Dergisi, (33), 87-106.

Başok Diş, S. (2017). Bentham ve Mill'in klasik faydacılığı bağlamında mutluluk problemi. Temaşa Erciyes Üniversitesi Felsefe Bölümü Dergisi, (7), 80-100.

Bell, M. L., \& Davis, D. L. (2001). Reassessment of the Lethal London Fog of 1952: Novel Indicators of acute and chronic consequences of acute exposure to air pollution. Environmental Health Perspectives, 109(3), 389-394.

Bernard, R. (1987). Imagery and theme in Hard Times. Charles Dickens' Hard Times, Harold Bloom (ed), New York: Chelsea House Publishers.

Bharadwaj, P., Zivin, J. G., Mullins, J. T., \& Neidell, M. (2016). Early-life exposure to the great smog of 1952 and the development of asthma. American Journal of Respiratory and Critical Care Medicine, 194(12), 1475-1482.

Black, J. (2003). Intussusception and the great smog of London, December 1952. Archives of Disease in Childhood, 88(12), 1040-1042.

Brantlinger, P. (1971). Dickens and the factories. Nineteenth-Century Fiction, 26(3), 270-285.

Butler, S. (1926). The way of all flesh. London, New York: AMS Press.

Butwin, J. (1977). Hard Times: The news and the novel. University of California Press. Nineteenth-Century Fiction, 32(2), 166-187.

Carlyle, T. (1843). Past and present / by Thomas Carlyle; ed. A.M.D.(1919). Hughes. Oxford: Clarendon Press.

Cevizci, A. (2000). Paradigma felsefe sözlüğü. İstanbul: Paradigma Yayınları.

Chapman, J. (1993). Leadership, management and "the effectiveness of schooling": A response to Mr Gradgrind. Journal of Educational Administration, 31(4).

Çiçekler, A. N. (2010), Sanayi devrimi döneminde Ingiltere'de çalışma koşulları: Charles Dickens romanlarından yansımalar. İstanbul Üniversitesi Sosyal Bilimler Enstitüsü, Yüksek Lisans Tezi, İstanbul.

Da Silva, T. V. Z., \& Lennard, A. (2000). Homo ludens and "esaú e jacó", homo economicus and "Hard Times": Literary representations of the nineteenth-century bourgeoisie. Portuguese Studies, 16, 43-51.

Devra L., Davis, C. M. L., \& Bell, T. F. (2002). A look back at the London Smog of 1952 and the half century since. Environmental Health Perspectives, 110(12), A734.

Dickens, C. (1861). Great expectations (20th ed.). London: Chapman and Hall. 
Dickens, C. (1954). Hard times. Great Britain: Collins Clear-Type Press.

Dickens, C. (2000). David Copperfield. New York: Modern Library.

Dickens, C., \& Nabokov, V. V. (1983). Bleak house. Toronto: Bantam Books.

Durkheim, E. (1893). The division of labor in society. New York: Free Press.

Fielding K. J. (1953). Charles Dickens and the department of practical art. The Modern Language Review, 48(3), $270-277$.

Fitzgerald, F. S.(1925). The great Gatsby (6th ed.). New York: Scribner Paperback Fiction.

Günay, D. (2002). Sanayi ve sanayi tarihi. Mimar ve Mühendis Dergisi, (31), 8-14.

Gürbüz, S., \& Şahin, F. (2014). Sosyal bilimlerde araştırma yöntemleri. Ankara: Seçkin Yayıncılık.

Henderson, J. P. (2000). Political economy is a mere skeleton unless: What can social economists learn from Charles Dickens?. Review of Social Economy, 58 (2), 141-151.

İspir, N. (2015). Habermas'ın sosyal bilimler eleştirisi. Atatürk Üniversitesi Sosyal Bilimler Enstitüsü Dergisi, 19 (2), 71 96.

Keskin H., Akgün A. E., \& Koçoğlu í. (2016). Örgüt teorisi. Ankara: Nobel Yayıncılık,

Makal, A. (2008). Türkiye emek tarihinin bir izdüşüm alanı olarak 'edebiyat." Çalışma ve Toplum, 3, 15-43.

Menteşe, D. (2015). Endüstri romanı: Shirley, Hard Times ve North and South. Ege Üniversitesi Sosyal Bilimler Enstitüsü, Yüksek Lisans Tezi, İzmir.

Mill, J. S. (1861). Utilitarianism. London: Fraser's Magazine.

Möngü, B. (2015). Modern dünyada mutluluk: Jon Sutuart Mill'in faydacı etiği. Atatürk Üniversitesi Sosyal Bilimler Enstitüsü Dergisi, 19(1), 23-30.

Neuman, W. L. (2017). Toplumsal araştırma yöntemleri nitel ve nicel yaklaşımlar (9. Baskı). (Çev. S. Özge). Ankara: Yayınodası.

Orwell, G. (1940). “Charles Dickens” inside the whale and other essays. Victor Gollancz. London.

Patricia, E. J. (1989). "Hard Times" and the structure of industrialism: The novel as factory. The Johns Hopkins University Press, 21(2), 128-137.

Pittock, M. (1998). Taking Dickens to task: "Hard Times" once more. The Cambridge Quarterly, 27(2), 107-128.

Rutli, E. E. (2014) Sosyal bilimlerde pozitivizm tartişmasi: Adorno ve popper. Temaşa Erciyes Üniversitesi Felsefe Bölümü Dergisi, 1(1), 134-160.

Saltan, I. D. (2009). İngilizce yazılmış bir romanın kaynak kültürdeki yeri ve Türkçe'ye çevirileri sonucunda erek kültürde aldığı yer. İstanbul Üniversitesi Sosyal Bilimler Enstitüsü, Yüksek Lisans Tezi, İstanbul.

Seker, F., \& Çetin, M. (2012). Faydacı refah ekonomisi: Amartya Sen'in eleştirisi. SÜ iïBF Sosyal ve Ekonomik Araştırmalar Dergisi, 12(24), 277-304.

Sönmez, V. (2010). Auguste Comte(1798-1857) pozitivizm (olguculuk). Dokuz Eylül Üniversitesi Hemşirelik Yüksekokulu Elektronik Dergisi, 3(3), 161-163.

Smith, A. (1948). Milletlerin zenginliği (Çev. Haldun Derin). İstanbul: Milli Eğitim Basımevi.

Spector, S. J. (1984). Monsters of Metonymy: Hard Times and knowing the working class. ELH, 51(2), 365-384.

Stoler, J. A. (1985). Dickens' use of names in Hard Times. Literary Onomastics Studies, 12(15), 153-164,

Şaylan, G. (2002). Postmodernizim. Ankara: Imge Kitapevi.

Torun, C. M. (2015). Insan bilimleri ve pozitivizm arasındaki gerilim. ETHOS: Felsefe ve Toplumsal Bilimlerde Diyaloglar, 8(1), 01-16.

Urgan, M. (2003). İngiliz edebiyatı tarihi (1. baskı). İstanbul: Yapı Kredi Yayınları.

Üskent, S. B. (2006). 19. yüzyıl İngiliz romanında endüstri devrimi'nin yansımaları: Dickens'ın Hard Times'ı, Gaskell'in Mary Barton'ı ve Disraeli'nin Sybil or the two Natıons'ı. Ankara Üniversitesi Sosyal Bilimler Enstitüsü, Yüksek Lisans Tezi, Ankara.

Wren, D. A., \& Bedeian, A. G. (2009). The evolution of management thought (Sixth Ed.). USA: John Wiley \& Sons Inc. 
This Page Intentionally Left Blank 